\title{
Szteroidok: A glükokortikoidok élettani és gyógyszertani hatásai
}

\author{
Zelena Dóra dr. - Makara B. Gábor dr. \\ Magyar Tudományos Akadémia, Kísérleti Orvostudományi Kutató Intézet, Budapest
}

\begin{abstract}
Az orvosi gyakorlatban kiterjedten alkalmazzák a glükokortikoidokat elsősorban az immunrendszer múködésének elnyomása, a gyulladásos folyamatok gátlása céljából. Másrészról a nevüket is adó Selye szerint az endogén molekulák az elsődleges megvalósítói a kihívásokhoz való alkalmazkodásnak, a stresszreakciónak. A glükokortikoidokat az 1940es években szintetizálták, és azóta számtalan adat látott napvilágot a termelődésükről (számos szervben lokálisan is), szállításukról (elsősorban a kortizolkötő globulinnal) és receptoraikról (magreceptor és nem genomiális hatások). Bár szabályozásuk elsődlegesen a hypothalamus-hipofízis-mellékvese tengely adrenokortikotropin hormonjának befolyása alatt áll, de számos egyéb molekula (elsősorban katecholaminok a mellékvesevelőből) is fokozhatja az elválasztásukat. Fő szerepük permisszív, azaz a glükokortikoidok számos egyéb molekula hatásának kifejtéséhez elengedhetetlenek (például katecholaminok). Így nagyon szerteágazó befolyással bírnak a metabolizmustól a cardiovascularis hatásokon át a csontanyagcseréig, még a központi idegrendszeri múködések szabályozására is kihatással vannak. A metabolikus szindróma kapcsán is előtérbe kerültek. Kiterjedt terápiás alkalmazásukat a mellékhatások problémássá teszik, amelyek kivédésére például az anabolikus dehidroepiandroszteron egyidejű adagolása is szóba kerülhet. Orv. Hetil., 2015, 156(35), 1415-1425.
\end{abstract}

Kulcsszavak: glükokortikoidok, receptorok, farmakokinetika, szerep, patofiziológia

\section{Steroids: The physiological and pharmacological effects of glucocorticoids}

Glucocorticoids are widely used in medical practice mainly for suppression of the immune system. According to Selye - who named them - the endogenous molecules are very important for the adaptation to challenges, stress. They were synthesized in the 1940s. Since then numerous data have been published about their production (also locally in several organs), transportation (primarily cortisol-binding globulin) and receptors (nuclear and non-genomic effects). Although glucocorticoids are primarily under the control of the hypothalamo-pituitary-adrenocortical axis, several other molecules (especially catecholamines) may also increase their secretion. Their permissive influences are dominant, thereby they are indispensable for the effect of numerous other molecules. Thus, glucocorticoids have very diverse influence from metabolism through cardiovascular effect to bone-metabolism, affecting even the central nervous system. They are also important in metabolic syndrome. Their extensive therapeutic usage are limited by side-effects, which could be diminished - among others - with concomitant usage of the anabolic dehydroepiandrosterone.

Keywords: glucocorticoids, receptors, pharmacokinetics, function, pathophysiology

Zelena, D., Makara, B. G. [Steroids: The physiological and pharmacological effects of glucocorticoids]. Orv. Hetil., 2015, 156(35), 1415-1425.

(Beérkezett: 2015. június 4.; elfogadva: 2015. július 2.)

\section{Rövidítések}

ACTH = adrenokortikotropin; $\mathrm{CAH}=$ congenitalis adrenalis hyperplasia; $\mathrm{CBG}=$ cortisol binding globulin; $\mathrm{COX}=$ ciklooxigenáz; $\mathrm{CRH}=$ kortikotropinelválasztást serkentő hormon; DHEA $=$ dehidroepiandroszteron; DHEAS $=$ dehidroepiand- roszteron-szulfát; DOC $=$ deoxi-kortikoszteron; $\mathrm{GC}=$ glükokortikoid; GR = glükokortikoidreceptor; $\mathrm{HHM}=$ hypothalamus-hipofízis-mellékvese; $\mathrm{MC}=$ mineralokortikoid; $\mathrm{MR}=$ mineralokortikoidreceptor 
A köznapi életben, ha valaki szteroidokat szed, az általában izomtömeg-növelés céljából anabolikus szteroidokat, tesztoszteronszármazékokat ért alatta. Az orvosi gyakorlatban a szteroidkezelés azonban elsősorban a glükokortikoidokkal (GC) immunszuppresszió, gyulladásgátlás céljából végzett beavatkozást jelent. A GC név alatt számtalan különféle endogén, illetve szintetizált molekulát értünk [1]. A molekulák hatása a kizárólag glüko- vagy a kizárólag mineralokortikoidhatás, mint két lehetséges szélsőség között helyezkedik el, azaz a legtöbb anyag mindkét hatással rendelkezik.

Az élettanban a GC-k neve egyet jelent a stresszválaszszal. A stressz fogalmát Selye definiálta [2], mint a szervezet nem specifikus válaszát mindenféle kihívásra, bár ez a fogalom az évek során jelentősen módosult. A stressz fajtája meghatározza a válasz természetét: szisztémás stresszorok (hideg, fájdalom) általában az agytörzs szint-

\section{STRESSZOR}

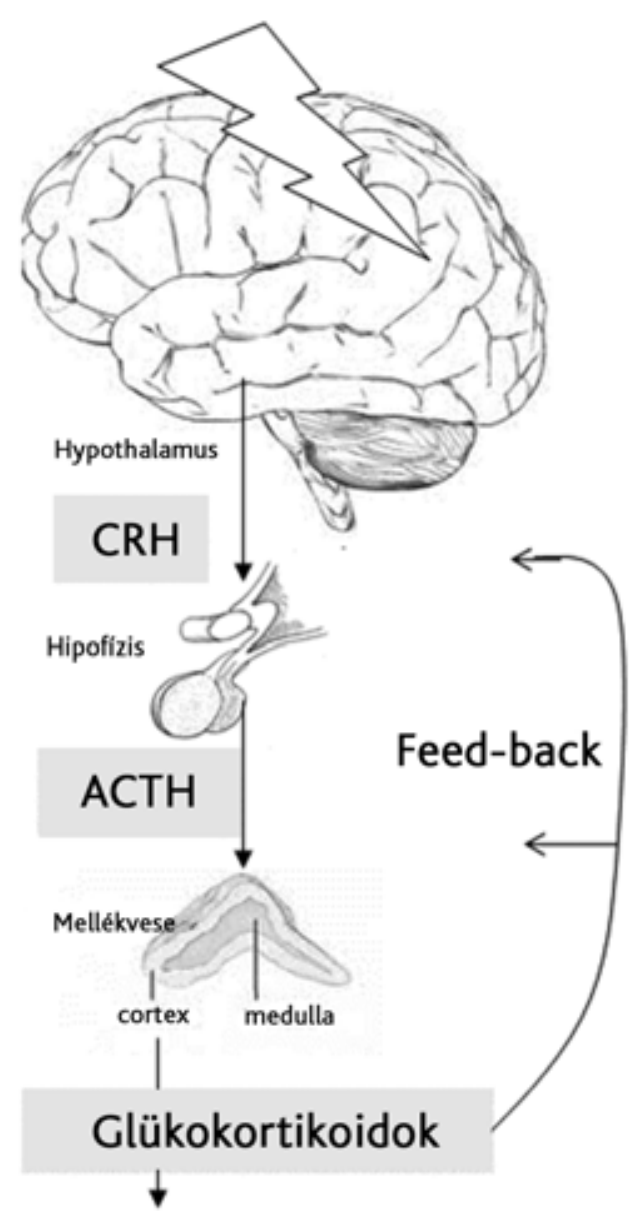

\section{HATÁS}

1. ábra $\quad$ A hypothalamus-hipofízis-mellékvese tengely szabályozásának klasszikus sémája

ACTH = adrenokortikotropin; $\mathrm{CRH}=$ kortikotropinelválasz tást serkentő hormon jén okoznak aktivációt, míg pszichogén stresszorok (megszokottól eltérő környezet, bezártság) a limbicus rendszeren keresztül. Mindenesetre Selye a stresszreakció végső közös útjának a hypothalamus-hipofízismellékvese (HHM) tengely aktiválódását tekintette (1. ábra). Ebben a folyamatban alapvető szerepet játszik a mellékvesekéreg és a benne termelődő GC-k. Maga a GC (de a mineralokortikoid - MC) elnevezés is Selyétől származik [3]. Mivel kezdetben az egyes szteroidok hatásait nem tudták élesen elkülöníteni, ezért az elnevezések is nehezen terjedtek el, de napjainkban széles körben polgárjogot nyertek.

A GC-k felfedezése az 1930-as években kezdődött, amikor az ízületi gyulladás fertőzéses teóriáját kezdte felváltani egy X-faktor keresése, amelyet Hench számos egyéb próbálkozás után a mellékvesében vélt felfedezni [4]. Kendall és Reichstein biokémikusokkal 28 anyagot izoláltak az 1940-es évekre, amelyekből 4-nek (A, B, E - más néven: $\mathrm{Fa}$ - és $\mathrm{F}$ anyagok) élettani hatása is volt. A munka heroikus volt, $1350 \mathrm{~kg}$ állati mellékvese kellett 1 gramm „A” anyag izolálásához. Az „E” anyag (compound E) különösen hatékonynak tưnt mellékveseirtott állatokon, és ezt kezdték azonosítani a keresett X-faktorral. Bár a második világháború közbeszólt, de 1948 szeptemberében sikerült annyi anyagot szintetizálniuk, hogy beadhassák az első ízületi gyulladásos betegnek. A 4 napos kezelés után az addig járóképtelen nő képes volt saját lábán elhagyni a kórházat. $\mathrm{Az}$ „E” anyag végül dehidrokortikoszteronnak bizonyult, s ezért a felfedezésért 1950-ben mindhárman Nobel-díjat kaptak. Azonban csak 1952-re sikerült kidolgozni a GC-szintézis nagyüzemi módszereit, amikorra már a betegek az egész világon az új terápia lázában égtek.

\section{A glükokortikoidok szintézise}

\section{A szintézis helye}

A GC-k a HHM-tengely harmadik szintjén, a mellékvesék kéregállományában szintetizálódnak, amely a kötőszövetes toktól a velőállomány felé haladva 3 részre tagolódik (2. ábra) [5].

A külső zona glomerulosa termeli a só- és vízháztartásért felelős mineralokortikoidokat (MC). A középső, legvastagabb zona fasciculata a stressztengely véghormonjának tekintett glükokortikoidok (GC) termelését végzi. A belső zona reticularis réteg szexuálszteroidokat termel (elsősorban dehidroepiandroszteront - DHEA és androszténdiont). A DHEA szulfatálódásának, azaz a DHEAS termelődésének kizárólagos helye a szervezetben ez a réteg. A DHEA anti-GC hatása miatt számos tanulmány szerint a kortizol/DHEA arányt célszerúbb vizsgálni pusztán a GC-szintnél [6].

Ezentúl a GC-k (és más szteroidok is) lokálisan számos szervben is termelődhetnek, például az elsődleges limfoid szervekben, bélben, bőrben, agyban és feltehetően a szívben is. Ezt a szintetizálóenzimek jelenléte, vala- 


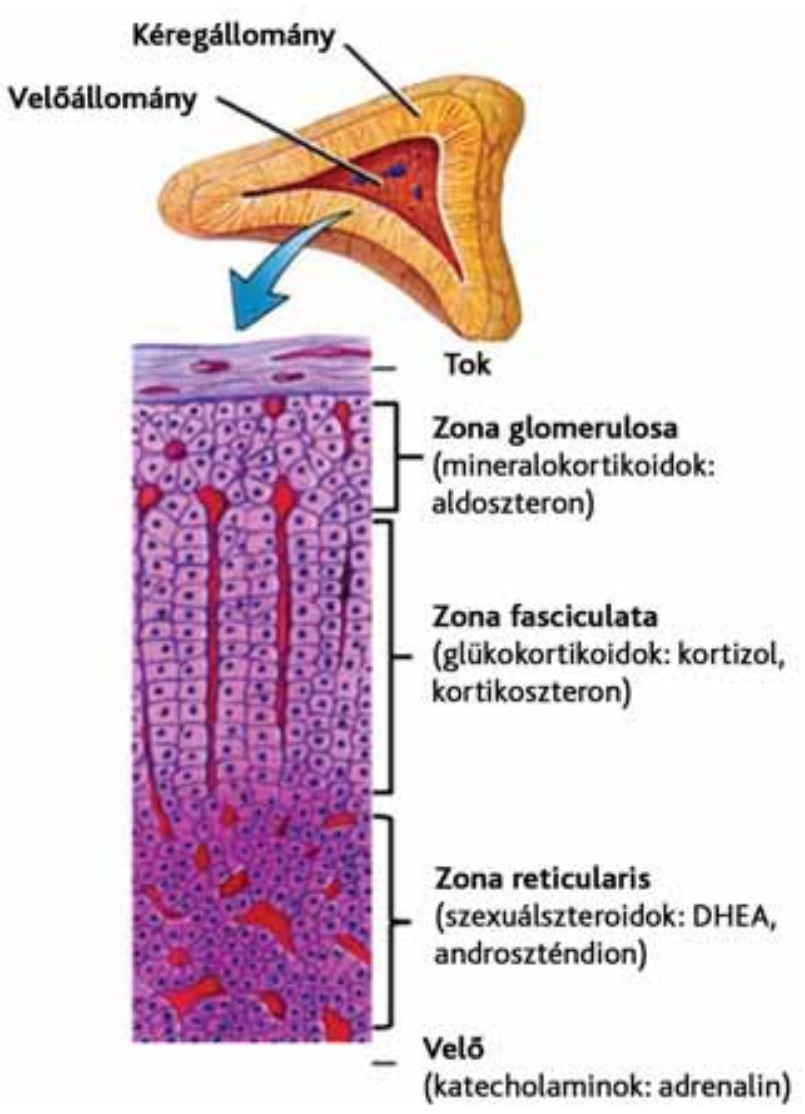

2. ábra

| A mellékvese szerkezete

mint a mellékveseirtás után is lokálisan magas GC-szint bizonyítja [7]. A bél epithelialis sejtjei a tápcsatorna szteroidjainak legfontosabb forrásai, és valószínúleg a helyi gyulladásos folyamatok szabályozásában vesznek részt.

\section{A szintézis lépései}

A folyamat kiindulási molekulája a koleszterin, amiból a mitokondriumokban található koleszterololdallánc-hasító enzim (steroidogenic acute regulatory protein) prognenolont állít elő [5]. Utóbbi molekulából az endoplazmatikus reticulum 3 - $\beta$-hidroxiszteroid-dehidrogenáz enzimének köszönhetően progeszteron képződik, amiból a 21-hidroxiláz (egy citokróm P450 enzim, újabb neve: CYP21A2) enzim deoxi-kortikoszteront (DOC) állít elő. Ebből a mitokondriumok 11-ß-hidroxiláz (CYPl1Bl) enzime segítségével kortikoszteron képződik. A kortizol csupán egy, a 17. szénatomhoz kapcsolódó hidroxilcsoportban tér el a kortikoszterontól. Ezt a 17- $\alpha$-hidroxiláz (CYP17) enzim helyezi fel a prognenolonra 17- $\alpha$-hidroxi-prognenolont képezve, amiből a kortikoszteron termelésénél említett 3 enzim segítségével 17- $\alpha$-hidroxi-progeszteronon és 11-deoxikortizolon át kortizol képződik.

A kortizol relatív GC hatása 1 , de azért 0,001 arányú MC aktivitása is van, míg az aldoszteron (a fó MC) 1 -es MC hatásához 0,15 arányú GC-hatás tartozik.
A kortikoszteron, amely rágcsálókban a fó $\mathrm{GC}, 0,4$-es GC és 0,004-es MC-aktivitású, míg a szintetikus dexametazon 100-szoros GC és 0,001-es MC-aktivitással bír.

\section{Mennyiség}

Az összes GC mennyisége a $100 \mathrm{ng} / \mathrm{ml}$-es (pmol $/ \mathrm{ml}$, nmol/l) tartományba esik, míg az MC koncentrációja $\mathrm{pg} / \mathrm{ml}(\mathrm{fmol} / \mathrm{ml}, \mathrm{pmol} / \mathrm{l})$.

A GC-k eróteljes napi ingadozást mutatnak, amelynek maximuma az aktív fázis elejére (emberben reggel 7 körül, rágcsálókban este 7 ) esik. Humán vizsgálatokban általában a reggeli órákban szokás mérni, és a hormon a véren kívül a nyálból és vizeletböl is kimutatható, valamint a hajban is felhalmozódik [8]. A mellékvesekéreg túltermelésével járó Cushing-szindróma esetén a ritmikus változások is hiányoznak.

A napi ritmusok kialakításában a GC-k ultradián, oszcilláló (rágcsálókban mintegy óránként jelentkező) elválasztása is szerepet játszik. A hormonrendszer szabályozásának egyik alapja, hogy a folyamatosan fennálló stimulus érzéketleníti a célszervet. Ezért a GC-oszcilláció alapvetően fontos az optimális génexpresszióhoz a célszervekben. Ennek fenntartásához viszont pulzatilis adrenokortikotropin (ACTH, a HHM-tengely második molekulája, 1. ábra) szekréciójára van szükség [9].

Valószínúleg magában a mellékvesében is van egy "óra" (pulzusgenerátor) [10], és ennek a múködését hangolja át a hypothalamus szuprakiazmatikus magjából jövő információ. A GC-k ritmusa pedig más szervek számára szolgál órajelként („Zeitgeber”).

\section{Farmakokinetika}

A vérben a GC-k 75\%-a egy májban termelődő plazmafehérjéhez, a transzkortinhoz (cortisol binding globulin - CBG) kötődve szállítódik, körülbelül 20\%-a aspecifikusan albuminhoz kötődik, bár ez utóbbi nagymértékben függ a táplálkozástól [11]. Csak a maradék, nagyjából 4-5\% szabad frakciónak van élettani hatása, ennek ellenére a legtöbb laboratóriumi módszerrel a teljes plazmakoncentrációt mérjük. Bár a CBG szintje akut stresszben drámaian nem változik, nemcsak passzív résztvevője a folyamatnak. CBG génkiütött (KO) egereken végzett kísérletek azt bizonyítják, hogy a GC-k gyors hatásaihoz (például memória) szükség van a kötőfehérjére, ami megvédi a GC-ket a lebontástól [12]. A CBG a szexuálszteroidok erőteljes befolyása alatt áll: szintjét az ösztrogének megemelik, és a progeszteron pedig kötődni képes hozzá. Ezek hatására a nőkben magasabb összGC-szinteket lehet mérni, ugyanakkora szabad aktivitás mellett.

A plazmában a GC-k fél életideje 60-90 perc, lebontásuk a máj P450 rendszerében történik, és a vesével választódnak ki a metabolitok [1]. Direkt kezelésekkel (felületi, ízületbe, belélegzett vagy epiduralis) bejuttatott GC-k elkerülik a májat és a „first pass” hatást. A génex- 
presszió befolyásolása miatt biológiai fél életidejük 24 órán túl van, de a hatás megjelenéséhez idő kell (a plazmakoncentráció ekkor sokszor már alacsony).

Az MC-k 40\%-ban szabad formában vannak (17\% CBG-hez, 47\% albuminhoz kötött, bár néhány tanulmány specifikus aldoszteronkötő fehérjéról is beszámolt [13]), de az aktív GC/MC arány még így is 100-szoros.

\section{Hatásmechanizmus}

\section{Genomiális hatások}

A GC-k és MC-k lipidtermészetüknél fogva egyaránt szabadon képesek a sejtek membránján diffundálni, fó hatásukat intracelluláris magreceptorokon keresztül fejtik ki. Két receptortípus van, amelyek egyaránt képesek a GC-ket és MC-ket is megkötni, de affinitásuk, eloszlásuk jelentősen eltér egymástól.

A II. tipusú (GC) receptor (GR) alacsony GC-affinitással rendelkezik (Kd 2,5-5 nM). Szervezetünk csaknem összes sejtjén megtalálható. Az agyban a legnagyobb mennyiségben a kéregben és a hippocampusban mutatható ki. Teljestest-GR KO állatok megszületnek, de hamar elpusztulnak légzési elégtelenség következtében. A GR gátlása (például mifepristonnal) Cushing-szindrómában csökkenti a metabolikus szindrómát (hyperglykaemiát, inzulinrezisztenciát, elhízást).

$\mathrm{Az}$ I. tipusú (MC) receptor (MR) elsősorban aldoszteron megkötésére szolgál, de hatékonyan képes GC-ket is megkötni $(\mathrm{Kd} \approx 0,5 \mathrm{nM})$. Legnagyobb mennyiségben a vesékben található, ahol a só- és vízháztartás szabályozásában vesz részt. Az agyban a GR-receptoroknál kisebb mennyiségben van jelen, elsősorban a hippocampusban, míg a hypothalamusban és a hipofízisen egyáltalán nem mutatható ki. Az MR-ek aktivációja elősegíti a gyulladást, a cardiovascularis átrendeződést, valamint befolyásolja a zsírszövet differenciálódását és anyagcseréjét is. Részt vehet mind az MC-k, mind a GC-k metabolikus hatásainak közvetítésében.

A két receptor alapszerkezete megegyezik, 3 fó doménnel rendelkeznek. A C terminális szakasz a ligandkötő hely, a hormonspecificitásért felel. Az N terminális szakasz a transzkripció stimulálásában játszik szerepet. A kettő között a DNS-kötő domén helyezkedik el, amely konzervatív szekvenciájával („zinc finger”) a génspecifikus hormonhatásért felel. Alapállapotban hősokkfehérjék (Hsp-70, Hsp-90) kapcsolódnak hozzájuk, amelyek inaktivált állapotban tartják a receptorokat. Hormon kapcsolódása esetén a hősokkfehérjék - amik önmaguk is specifikus hatásokért felelősek - leválnak és a kialakult szteroidreceptor-komplex bejut a sejtmagba. Foszforilálódás után két komplex homodimer formában összekapcsolódik, és a DNS megfelelő régiójához (glucocorticoid response element) kötődve transzkripciós faktorként szabályozza (serkenti vagy gátolja) több ezer gén átíródását [14]. Más transzkripciós faktorok is szükségesek a megfelelő múködéshez, és az átírt molekulák maguk is to- vábbi folyamatokat stimulálhatnak vagy gátolhatnak. A GC-válasz sokszínúségét fokozza az egyetlen receptorgénből „alternatív splicing” révén keletkező változatok, valamint a poszttranszlációs módosulások hatására keletkező számos receptoraltípus jelenléte.

A GR és MR közötti lokalizációs és affinitáskülönbségek a GC-elválasztás időbeli dinamikájában és a stresszre adott válaszreakciók kialakításában is kulcsfontosságú szerepet játszanak. Normális, stresszmentes körülmények között a MR-ek nagy része telített (70-90\%-os telítettség), míg a GR-ek nagyfokú telítődése csak stressz során figyelhető meg, amikor a GC-visszacsatolásban vesznek részt. Az MR/GR arány kiegyensúlyozatlansága esetén zavar támad a HHM-tengely múködésében, ami fokozza az egyén vulnerabilitását [15].

\section{Nem genomiális hatások}

A GC-k néhány perc alatt bekövetkező, génexpressziótól független magatartási válaszokat is képesek kiváltani, amiket gyors, nem genomiális hatásoknak nevezünk [16]. Ennek mechanizmusa kevéssé ismert, de több lehetséges mediátort leírtak. Elképzelhető, hogy a genomiális mechanizmust is közvetítő receptorok rendelkezhetnek ezzel a hatással, mivel néhány kísérletben a GR-receptorok gátlása a gyorsan megjelenő GC-hatásokat is blokkolta. Más gyors hatások $\mathrm{Ca}^{2+}$ jelenlététól függtek [17], és egyes gyors hatások dexametazonnal is kiválthatók voltak.

Az MC-k vonatkozásában is leírtak hasonló, gyors, nem genomiális hatásokat [18].

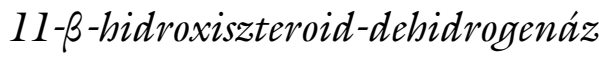

$\mathrm{Az} \quad \mathrm{MC}$ célszervekben (például vese) található 11- $\beta$-hidroxiszteroid-dehidrogenáz-2 (11ßHSD2) inaktiválja a GC-ket, amelyek így nem képesek MR-receptorhoz kötődni (3. ábra). Ezzel szemben a 11- $\beta$-hidroxiszteroid-dehidrogenáz-1 (11ßHSDl) a GC-k aktiválását végzi (számos más molekula metabolizmusa mellett), így fokozva a GC célszervekben (például máj) a kívánt hatást. A jelenséget prereceptorspecificitásnak nevezzük. Nagy mennyiségű kortizol jelenléte ese-

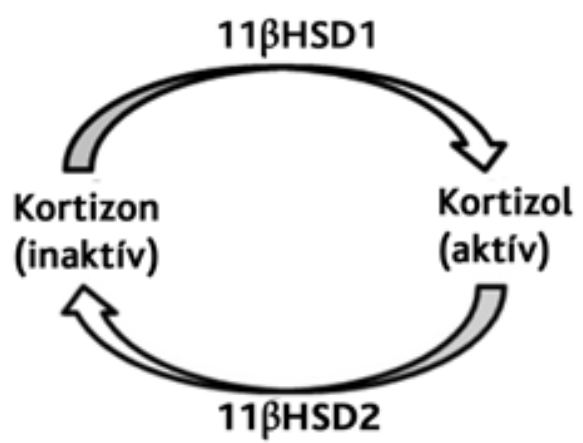

3. ábra $\mid$ A glükokortikoidokat aktiváló és inaktiváló 11-ß-hidroxiszteroiddehidrogenázok (11ßHSD) 
tén (például Cushing-szindróma) előfordulhat, hogy az enzim nem képes az összes molekulát inaktiválni, így a GC-k MC-szerú hatásokat is létrehoznak. Néhány publikáció alátámasztja, hogy egyes esetekben az aldoszteron is képes lehet GR-receptoron keresztül hatásokat kifejteni [19].

\section{Szabályozás}

A HHM-tengely müködésének megfelelően a GC-elválasztás legfontosabb, tankönyvekben kizárólagosan említett szabályozója az ACTH, bár a HHM-tengely hypothalamicus komponensének (1.ábra), a kortikotropinelválasztást serkentő hormonnak (CRH) [20], illetve ACTH hiányában is [21] megemelkedhet a GC-k szintje. Állatkísérletekben az immunrendszert befolyásoló ízületi gyulladásos modellben nagy valószínúséggel az immunmediátorok (például tumornekrózis-faktor- $\alpha$, interleukin-6, galaninszerű peptid) közvetlenül a hipofízis ACTH-termelését serkentheti. Ennél is meglepőbb volt azonban, hogy a cukorbetegség modelljében a hipofízis ACTH-elválasztásának szabályozása ugyan a hypothalamusból jövő faktoroknak volt köszönhető, de a mellékvese fokozott GC-termelése az ACTH-termeléstől függetlenül kialakult. Ez felvetette egy közvetlen, a mellékvesekéregre irányuló szabályozás lehetőségét. Valóban, cukorbetegség alatt számos humorális faktor található a vérben, megváltozik a mellékvese szabályozófaktorok iránti érzékenysége is, továbbá előtérbe kerülhet a mellékvese-beidegzés szabályozószerepe is.

\section{ACTH-független glükokortikoidszabályozás}

Állatkísérletes vizsgálataink során sokszor azt tapasztaltuk, hogy a GC-k szintjének változása nem követte az ACTH-ingadozásokat [22]. Számos méréstechnikai probléma is állhat ennek a hátterében:

1. Mivel az ACTH-elválasztást a GC-növekedés némi késéssel követi, az esetek egy részénél a disszociáció hátterében csupán a mintavételezés időzítésének helytelen megválasztása áll. A HHM-tengely különféle hormonjai emberekben is időbeli eltolódással mutatnak csúcsértékeket. Számos kísérletünkben sorozatvérvétellel zártuk ki ezt a magyarázatot.

2. További méréstechnikai probléma lehet, hogy a CBG-szintek eltérései jelentős össz-GC-szint-különbségekhez vezethetnek a szabad szintek eltérései nélkül. Ennek a szerepét is sikerült kizárnunk.

3. Az is elöfordulhat, hogy az egyes csoportokban a mellékvesekéreg fokozott ACTH-érzékenysége vezet ACTH-GC disszociációhoz. Ennek tanulmányozására in vitro mellékvese-szekréciós vizsgálatokat végeztünk, és bebizonyítottuk, hogy ez sem magyarázza teljes mértékben a disszociációt.

Ha kizárjuk a fent említett méréstechnikai problémákat, akkor fel kell tételeznünk egy ACTH-független GC-szekréció meglétét. Bornstein és munkatársai szá- mos lehetséges mediátort foglaltak össze [23], mégis a GC-elválasztás serkentésére legkézenfekvőbbnek a stressz során szintén aktiválódó mellékvesevelőből származó katecholaminok tűnnek. Valóban, valamennyi katecholaminreceptor megtalálható a mellékvesekéreg GC-termelő sejtjein, de talán legjelentősebbek a $\beta$-receptorok, amelyek a splanchnicus beidegzés hatásait közvetíthetik. Endogén jelentőségüket in vivo rendszerben is sikerült igazolnunk [22].

További lehetőségként merült fel, hogy az ACTHszintek változásait tulajdonképp a GC+MC szintek együttesen követik [24]. Bár vizsgálataink ezt nem igazolták, de azt találtuk, hogy 10 napos kispatkányban akut stresszorok hatására elsősorban az aldoszteron szintje emelkedik, míg felnőtt állatokban sokkal nagyobb mérvű a kortikoszteron- (mint fó rágcsáló GC) emelkedés.

Összegezve: Eredményeink is alátámasztják az úgynevezett paraadenobypophisealis neuroendokrin szabályozás elméletét [25], és arra utalnak, hogy perinatalis korban az MC-k akut, stressz alatti szabályozása (például a sóvíz háztartás fenntartása érdekében) nagyobb jelentőségü lehet, mint a GC-k szerepe (például a figyelem fokuszálása).

\section{Hatások}

A GC funkcióit több csoportba sorolhatjuk [26]: A korai hatások közé tartoznak 1. a serkentő, védekezést fokozó folyamatok, míg a késői hatások között szerepelnek a 2. szuppresszív, gátlóhatások, amelyek a hormonális „túllövést” akadályozzák meg, valamint a 3 . preparatív és 4. permisszív hatások, amelyek a következő stresszor előtt hatva, az arra való felkészülést segítik, a „rendelkezésre állást” biztosítják. Az akut és krónikus hatások az egyes szervek, szervrendszerek esetén átfedést mutatnak. A direkt hatásokon túl más hormonok, molekulák hatásait is kiterjedten befolyásolják.

A homeosztatikus egyensúly értelmében a GC-knek van egy optimális szintje. A túl sok, de a túl kevés is betegségekhez vezethet (fordított U mintázat [27], 4. ábra). Ennek egyik lehetséges celluláris mechanizmusa, hogy számos sejten kétféle (GR és MR) receptor is lehet, és ezek ellentétes hatásokat generálhatnak. Másik, elsősorban a perifériás szervekben megvalósuló mechanizmus, hogy a GC-k mennyiségüktől függően ellentétes hatást gyakorolhatnak a generált szignálmolekulák (például citokinek) mennyiségére, illetve megváltoztathatják a célszervek szignálmolekulák iránti érzékenységét.

\section{Anyagcserehatások}

A GC-k metabolikus szerepe a szervezet energiatartalékainak mozgósítása, amire a nevük is utal [28]. Energiaszubsztrátokat (glükózt, aminosavakat, szabad zsírsavakat) mobilizálnak, hogy ezek rendelkezésre álljanak a mitokondriális oxidáció számára a „flight or fight”, akut 


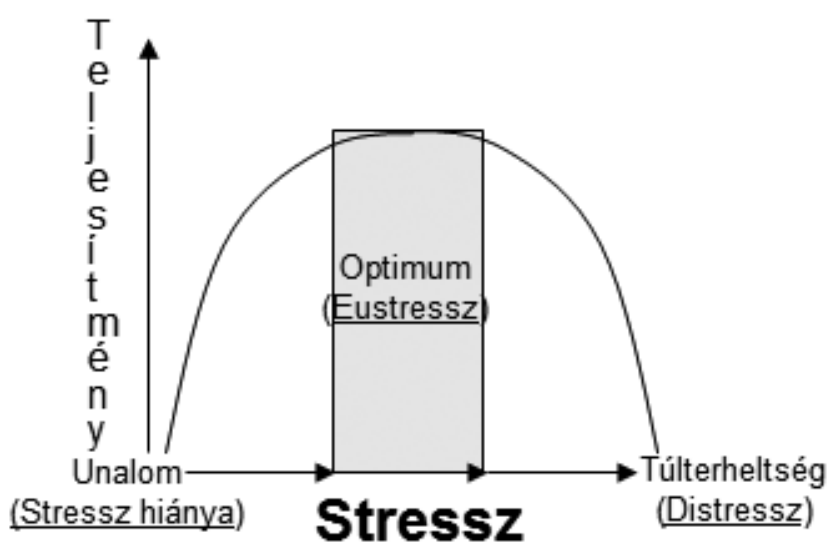

4. ábra

Stressz a szervezetben. A stressz optimális szintje (eustressz) szükséges a megfelelő teljesítményhez. Nemcsak a túl sok, hanem a túl kevés stimulus is káros

stresszreakció kapcsán. A GC-k katabolikus hatását a DHEA-k anabolikus hatása ellensúlyozhatja.

Hatásukat elsősorban nem közvetlenül az enzimaktivitások befolyásolásával érik el, hanem biztosítják a katabolikus hatások enzimatikus hátterét (permisszív hatás), felerősítik és meghosszabbítják az akutan ható hormonok (például katecholaminok, glükagon, növekedési hormon) hatásait. Ezzel összhangban éhezés során szintjük nem nő, viszont GC-hiányos (például mellékveseelégtelenség: Addison-kór) egyedek rosszul tûrik az éhezést.

A szénhidrát-anyagcsere több lépésére közvetlenül is hatnak, összességében hyperglykaemizáló hatásúak. Ennek egyik tényezője a glükoneogenezis elősegítése, ami részben az enzimek szintjének növelésével, részben a sejtek (elsősorban az izom) fehérjebontó aktivitásának növelésével és fehérjeépítő folyamatok csökkentésével valósul meg. Így több aminosav áll rendelkezésre a májban a glükoneogenezishez. Növelik a zsírok, zsírsavak bontását (elsősorban a végtagok területén), gátolják a lipogenezist is, ami glicerint bocsát a glükoneogenezis rendelkezésére, valamint szabad zsírsavakat az energiatermeléshez.

A hyperglykaemia további tényezője a szövetek, elsősorban az izom- és zsírszövet glükózfelhasználásának csökkenése a glükóztranszporterek membránból való visszavétele révén.

A GC-k számos szövetben inzulinrezisztenciát hoznak létre, ami szintén hozzájárul a vércukorszint-növelő hatáshoz. Ennek egyik lehetséges mechanizmusa a szabad zsírsavak szintjének emelésén keresztül történő hatás.

A szénhidrát-anyagcserére gyakorolt paradox hatás a máj glikogénszintézisének növelése, mivel ez a vércukorszintet csökkenti. A raktárak feltöltése viszont a rendelkezésre állást, a következő stresszorral való megküzdést biztosíthatja.

A zsirszövet múködésére a GC-k komplex és kontextusfüggő hatással vannak, ami függ a fajtól, a zsírraktárak nagyságától és a GC-k mennyiségétől, valamint a hatás időtartamától. A fentebb említett lipolízissel ellentétben például krónikus hatásuk a praeadipocyták differenciációjának segítése, és a centrális testtájakon lipogenezis (lásd: Cushing-kórban centrális elhízás). Illetve hiányuk is fokozza a lipolízist, ami részben megmagyarázhatja a mellékvese-elégtelenségben megfigyelhető cachexiát, elsorvadást.

Mindezek összességeként a GC-k alapvető jelentőségűek a metabolikus szindrómában.

Ezenkívül a magatartáson keresztül is befolyásolják a táplálékfelvételt [29], feltehetően az orexigén és anorexigén molekulák szintjének befolyásolása révén, de ez a folyamat a HHM-tengely egészét tekintve bonyolult összefüggéseket mutat (5. ábra).

\section{Immunrendszerre gyakorolt hatások}

A klinikumban kiterjedten használják a GC-ket az immunrendszert és a gyulladásos folyamatokat gátló hatásaik miatt. Ezen hatásukat számos mechanizmuson keresztül fejtik ki.

A teljesség igénye nélkül például csökkentik számos, proinflammatorikus citokin (interleukin-1, interleukin-6, tumornekrózis-faktor- $\alpha$ ) szintézisét, felszabadulását, hatékonyságát (például receptoruk mennyiségét, az általuk aktivált transzkripciós faktorok hatását csökkentve). Továbbá csökkentik egyéb gyulladásos mediátorok szintézisét (hisztamin, bradikinin, nitrogén-monoxid, eikozanoidok) - részben a foszfolipáz $\mathrm{A}_{2}$ (a fokozott lipokortinelválasztás révén), részben a cikloxigenáz- (COX-) aktivitás gátlásával - vagy fokozzák a lebontásukat, eliminációjukat. A májban csökkent az akutfázis-fehérjék (szérumamiloid, C-reaktív protein, komplementfehérjék) szintézise is.

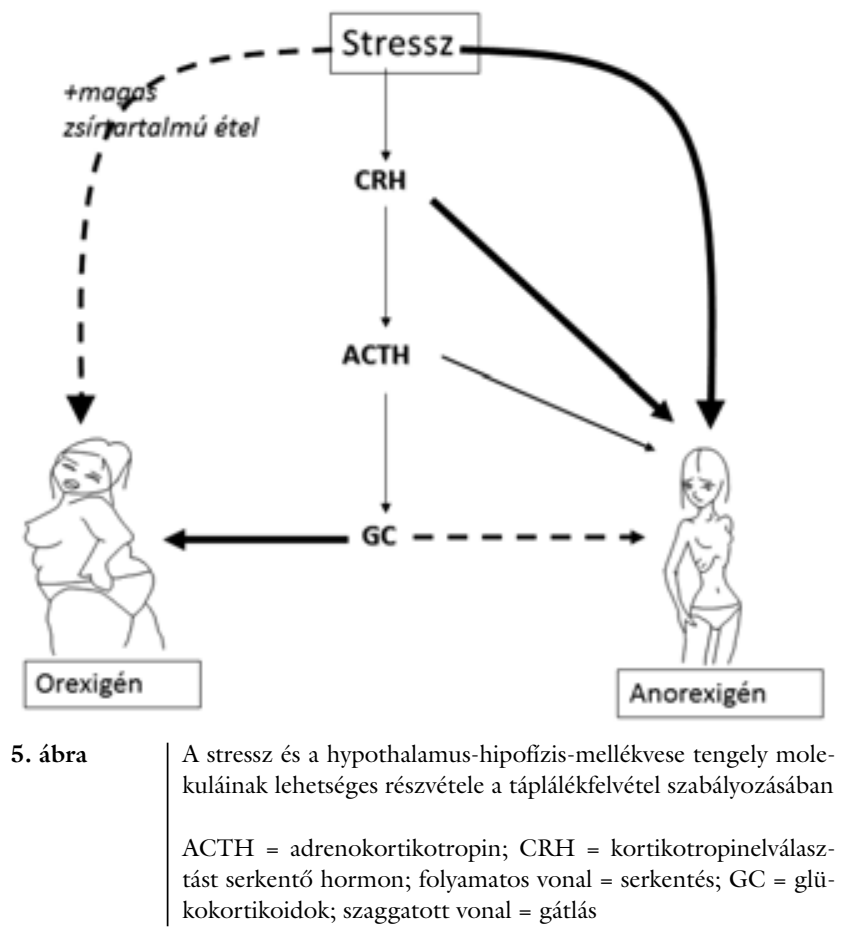


A sejtes elemek szintjén fokozzák az immunkompetens sejtek prekurzorainak apoptózisát, csökkentik a T-sejtproliferációt, monocyta-macrophag rendszer differenciációját (granulocyta-macrophag kolóniastimuláló faktor csökkent képződése révén), valamint csökkentik a keringő lymphocyták mennyiségét. Csökkentik az értágulatot és az erek átjárhatóságát is.

A terápiás hatással ellentétben fontos hangsúlyozni, hogy a többi szervrendszerre gyakorolt hatással összhangban a GC alapszintje szükséges a normális, adaptín immunválasz kialakításához [30]. Akut stresszorok hatására elsődlegesen a katecholaminokon keresztül aktiválódik az immunrendszer. A katecholaminok termelődéséhez és hatásaihoz pedig GC-k szükségesek (permisszív hatás).

A GC-k akutan serkentik az immunsejteknek az erekből való kilépését és a szövetekben való felhalmozódását is, ami szintén adaptív, a szükséges helyen állítja csatasorba az immunrendszert. Előzetes akut stresszor segíti egy későbbi immunválasz aktiválódását is („priming” hatás). Például az elkerülhetetlen sokk fokozta a 24 óra múlva lipopoliszacharid- (Gram-negatív sejtfal, a bakteriális fertőzés modellje) injekcióra létrejövő citokinválaszt [31].

Krónikus GC-emelkedés esetén azonban az immunszuppresszív hatások dominálnak.

\section{Só-viz háztartás}

Egyik indirekt hatása a vazopresszinre (mint a HHMtengely szabályozásában is részt vevő antidiuretikus hormonra) gyakorolt negatív visszacsatolás a hypothalamusban. Azaz GC-hiányban vízretenció alakulhat ki.

A pitvarokban termelődő atriopeptin (atrial natriuretic peptid) átírásához is szükséges, azaz hiányában sóretenció is bekövetkezhet.

Nem ismert mechanizmus szerint a vesében a normális glomerulusfiltráció fenntartásához is nélkülözhetetlenek a GC-k.

Ezenfelül extrém mértékü GC-szint az MR-receptorok ingerlése révén aldoszteronszerü hatásokat is képes kiváltani.

\section{Cardiovascularis hatások}

A só- és vízháztartás szabályozásán keresztül az artériás nyomás fenntartásában is fontos szerepet töltenek be.

A keringésre elsősorban ható szimpatikus noradrenerg beidegzést a GC-k több ponton befolyásolják. Emelik a receptorszámot, segítik a receptorok kapcsolódását G-fehérjéhez, meghosszabbítják a katecholaminok hatását. Mindezek hatására nő a cardiovascularis válaszkészség a szimpatikus beidegzésre, azaz elsődlegesen érösszehúzódás $(\alpha \mathrm{l})$, valamint a szívben $(\beta \mathrm{l})$ pozitív chronotrop (szívfrekvencia), inotrop (összehúzódás ereje), bathmotrop (ingerlékenység), dromotrop (ingerületvezetés) és luzitrop (ellazulás) hatások jönnek létre.
A renin-angiotenzin rendszer (az aldoszteron legfőbb szabályozója) megfelelő múködéséhez, az angiotenzinogén májbeli szintéziséhez és az erek angiotenzin II iránti érzékenységéhez is szükséges megfelelő GC-szint.

Közvetlen hatásként gátolják számos prosztaglandin és a nitrogén-monoxid szintézisét (lásd immunfunkció), ezáltal az általuk okozott értágulatot is.

Mindezek hatására a GC-k hiánya is jelentősen hozzájárul (az MC-ken túl) az Addison-kórban tapasztalható csökkent vérnyomáshoz, míg emelkedett GC-szint ( $\mathrm{Cu}$ shing-szindróma vagy exogén GC-bevitel) hypertoniát okozhat.

A simaizmokra gyakorolt hatás a légutak adrenerg relaxációjának ( 32 ) segítésében is megnyilvánul.

\section{Csont- és kötöszöveti müködés}

Bár fiziológiás hatásai nem világosak, de mind magas szintjük, mind terápiásan magas GC-koncentráció esetén csökkent csont- és kötőszövet-képződést, a növekedés visszamaradását tapasztalhatjuk.

Gátolják az osteoprogenitor sejtek differenciációját, valamint az osteoblast-aktivitást, és fokozzák az osteoclastok tevékenységét. (A RANKL/OPG arány fokozásával: az osteoblaston lévő receptor activator of nuclear factor kappa-B ligand a saját maga által termelt osteoprotegerin helyett az osteoclastokon lévő receptorához kötődve aktiválja azokat.) D-vitamin-antagonizmus révén csökkentik a kalciumfelszívódást a bélből és növelik a vesén keresztüli ürítést. Hatásukra csökken az osteoid szövet vázát képező kollagén szintézise is. Összességében felnőttben osteoporosishoz vezethetnek.

A kötőszövetben gátolják a mátrixfehérjék szintézisét, valamint a helyi növekedési faktorok és egyéb citokinek termelődését is. Ezért bár a lokális gyulladásos folyamatok gátlása előnyös lehet, de a sebgyógyulás is elhúzódik. A bőr elvékonyodik, striák alakulhatnak ki.

\section{Fejlödési hatások}

Bár számos sejtvonal osztódását, differenciálódását gátolják, de intrauterin alapvetően szükségesek a megfelelő fejlődéshez.

Az egyik legfontosabb szerepük, hogy a tüdősejtek felületaktív anyagának (surfactant) a termelését fokozzák, amelynek megfelelő szintje alapvető az első légvétel során az alveolusok nyitva tartásában. Stresszmentes állapotban a GC-hiány egyetlen jól dokumentált halálos következménye a tüdő fejlődésének zavara. A CRH KO, valamint a GR KO egerek homozigóta utódai súlyos tüdőelváltozásokban pusztulnak el nagyon fiatalon. De ha az anyát GC-vel kezelték a terhesség alatt, akkor az utódokban nem alakult ki légzési elégtelenség. Az exogén adott GC hatása azonban kétfázisú: túl nagy adagok csökkenthetik a surfactantképzést.

Bár számos állatban a GC-k fontos szereppel bírnak a szülés megindításában, humán adatok ezt nem teljesen 
támasztják alá [32]. Az exogén GC-k ugyanis visszaszoríthatják az endogén szteroidszintézist, ezzel együtt az ösztrogének szintje is csökken. Márpedig a GC-k szülést megindító hatásához nélkülözhetetlen a magas ösztrogénkoncentráció.

\section{Központi idegrendszeri hatás}

A hippocampus - úgy is, mint a GC-visszacsatolás fó helye - kitüntetett szereppel bír. Ebben a vonatkozásban is legismertebbek a krónikus GC-emelkedés negatív (atrofizáló: csökkent neurogenezis és dendrittüske-mennyiség), memóriarontó hatásai. A GC-k számos érzelmi zavar (szorongás, depresszió [33]), de más pszichiátriai kórkép (például szkizofrénia) kialakulását is elősegíthetik. Mind az Engel-féle biopszichoszociális modell [34], mind DeKloet általi kísérletes kiterjesztése, a „three hit theory” [35] szerint a pszichiátriai betegségek legtöbbje 1. genetikai hajlam talaján, 2. a negatív korai életesemények által megzavartan kifejlődött egyént érő, 3. akut kihívásokra adott zavart reakció. Ebben az értelemben a korai negatív életesemények krónikus stresszben tarthatják az illetőt, és egy akut stressz válthatja ki a tünetek megjelenését.

Ezzel ellentétben a GC-k szintjének akut emelkedése fokozza a szinaptikus plaszticitást, csökkenti az apoptózist és elősegíti a hippocampusfüggő tudati múködéseket; mintegy a figyelem a veszélyre fokuszálódik. Valóban, a tanulási folyamatok enyhén stresszes állapotban fokozódnak, viszont az emléknyomok felidézése sokszor zavart szerved [36]. A központi idegrendszerben akut stresszhatásra fokozódik a gyulladásos mediátorok (nuclear factor kappa- $B$, tumornekrózis-faktor- $\alpha$, nitrogénmonoxid stb.) szintje, valamint a perifériához hasonlóan itt is létrejön a „priming” hatás. Érdekes módon, ha a GC-ket az immunválasz kialakulása után adjuk, akkor csökkentik azt. Továbbá agyterületenként is eltérő hatásokat tapasztalhattunk. Például a hypothalamusban és a frontális kéregben a GC-k serkentik, míg a hippocampusban gátolják bizonyos gyulladásos mediátorok termelődését.

GC-k számos egyéb adaptív és patológiás magatartás kialakulását is befolyásolják, többek között az agressziót [37]. Fontos a szerepük a hypothalamus-hipofízis-gonád tengely és a szexuális viselkedés stressz alatt megfigyelhető gátlásában is. A HHM-tengely hormonjainak, illetve antagonistáinak adása számos fajban, így emberben is jellegzetes, EEG-vel követhető alvásmintázat-eltéréseket okoz. Például egyetlen kortizolinjekció növeli a nonREM (rapid-eye-movement) alvás mennyiségét.

Az általános vélekedés szerint a stressz okozta túlzott GC-emelkedés okoz patológiás elváltozásokat, de az U alakú hatásspektrum arra utal, hogy a csökkent stresszreaktivitás legalább olyan káros lehet. Például azokban az egyénekben, akik egy traumatizáló élményre alacsonyabb GC-szekrécióval reagáltak, később nagyobb valószínúséggel alakul ki poszttraumás stressz zavar [38].
A GC-kre adott csökkent válasz legszembetûnőbb példái a depressziósok, akik gyakran csökkent dexametazonszuppressziót mutatnak. A dexametazon a hipofízisen keresztül negatív visszacsatolással a HHM-tengely müködését és így a GC-k elválasztását is csökkenti. Alacsony dózisú (1-2 mg) dexametazonszuppressziós teszt az egészséges egyénekben csökkenti a GC-k termelését. Nagyobb dózis $(8 \mathrm{mg})$ a hipofízis patológiásan magas ACTH-termelését képes csökkenteni, de ectopiás szervekét nem (azaz a centrális és perifériás Cushing elkülönítésére alkalmas). Éjfélkor adott dexametazon után másnap reggel 8-kor kell vérmintát venni.

Néhány szerző úgy gondolja, hogy a fenti adatok extrém (túl alacsony vagy túl magas) GC-szintek hatásainak tanulmányozásából születtek, azaz nem tükrözik kellően a fiziológiás szerepet [39]. A pontos fiziológiás hatás feltárása még várat magára.

\section{Az ACTH extraadrenalis hatásai}

Számos kísérletben azt is tapasztaltuk, hogy az ACTHelválasztás a GC-től függetlenül szabályozódik, így felmerült, hogy a stresszfolyamatok során megemelkedett ACTH nem kizárólag a GC-szintek szabályozásában vesz részt [40].

A nyugalmi ACTH-szint nemcsak a mellékvese múködésének fenntartásában, hanem annak fejlődése szempontjából is kiemelt fontossággal bír. A stressz által kiváltott ACTH-növekedés a GC-hormonok szintézisén és felszabadításán túl a mellékvese MC- és androgén hormonjainak termelődésére is hatással van. A szteroidhormon-szintézis fokozására a mellékvesén kívül más szteroidtermelő szövetekben is képes.

Ezzel összefüggésben, intézetünkben folyó kutatások már a '60-as években igazolták, hogy az ACTH a petefészkek vérellátásának szabályozásában is jelentős szerepet vállal. Szíp-és érrendszeri hatásai közé tartozik még a vérnyomásnövelő hatás, a lokális véráramlás fokozása és a só- és vízháztartás szabályozása a natriuresisen keresztül.

A GC-khez hasonlóan az ACTH is rendelkezik direkt gyulladásgátló hatással. Mind a keringő lymphocyták, mind a csecsemőmirigy múködését képes befolyásolni. A szénhidrát- és lipidanyagcserére gyakorolt hatásait agyban, májban, hasnyálmirigyben és barna zsírszövetben is tanulmányozták. Az ACTH direkt szerepet játszik a hőszabályozásban, és szintje a táplálékfelvételre is hatással van. Ezenkívül enyhe hatást gyakorol az izommüködésre és a csontképződésre is, továbbá a bőr pigmentáltságára is hatással van. Utóbbi háttere, hogy a melanocytastimuláló hormon az ACTH első 13 aminosava. Exogén melanokortinok erős hatást gyakorolnak a viselkedésre, bár endogén hatásuk kevésbé bizonyított.

Az ACTH fent bemutatott mellékvesén kívüli hatásai nemcsak kutatási, hanem diagnosztikai és terápiás használat szempontjából is érdekesnek ígérkeznek például csecsemőkori görcsökben, epilepsziában és a lipidcsökkentő hatás miatt. 


\section{Klinikai kórképek}

Leggyakrabban a GC-k túlsúlya vezet klinikai tünetekhez [41]. A bármely okból keletkezett hypercortisolismust Cushing-szindrómának nevezzük. Leggyakrabban (70-80\%) a hipofízis ACTH-hiperszekréciója az ok (adenoma), amit Cushing-kórnak vagy centrális Cushingnak hívnak. Létrejöhet még mellékvesetumor (10-15\%) vagy ectopiás ACTH-termelő daganat következtében is. A legfontosabbak mégis a terápiás célból alkalmazott GC-k, amelyek iatrogén Cushing-szindróma kialakulásához vezethetnek.

Speciális elhízás (holdvilágarc, centrális lerakódás vékony végtagokkal), a csont- és kötőszöveti problémák miatt bölénypúp és elődomborodó has jellemzi a beteget. Gyengeség, fájdalmak, magas vérnyomás, bőrproblémák (acne, fertőzések, rossz sebgyógyulás, striák, vérzések), szexuális problémák (cikluszavar, impotencia), szomjúságérzés és pszichés labilitás mind előfordulhatnak. A probléma kezelése elsősorban mütéti.

A GC-k hiánya általában nem izoláltan jelentkezik, és akutan viszonylag ritkább. Krónikus mellékvese-elégtelenség (Addison-kór) régebben tuberculosis miatt alakult ki. Ma inkább az autoimmun változat a gyakoribb, illetve antikoagulánsok szedését követően bevérzés is előfordulhat. Beszélhetünk primer, a mellékvesét elsődlegesen érintő megbetegedésen túl másodlagos, a hipofízis ACTH-termelésének, illetve harmadlagos, a hypothalamus CRH-termelésének csökkenésével járó kórképről is.

A tüneteket az MC-k hiánya dominálja: keringési zavarok, gyengeség, fáradékonyság, idegi és szellemi ingerlékenység jellemzik. Hiperpigmentáció az ACTH-túltermelés miatt alakulhat ki. Kezelésében a hiányzó GC és MC pótlása jön szóba.

Jellemző még a szintézis egyes enzimjeinek hibás müködése. A hiányzó anyagok hibás negatív visszacsatolása miatt az ACTH-szintézis fokozódik és ez a mellékvese hyperplasiájához (congenitalis adrenalis hyperplasia $\mathrm{CAH}$ ), valamint a defektus előtt lévő termékek felhalmozódásához vezet. Leggyakoribb (90\%) a CYP21 hiánya, amikor sem aldoszteron, sem kortizol, de még DOC sem képződik, azaz teljes az MC-hiány is (sóvesztéses forma). Viszont a szintézis az androgének felé terelődik (virilizáció).

A CYP11Bl enzim hiánya DOC-felhalmozódással, azaz sóretencióval és magas vérnyomással jár. A többi enzimdefektus előfordulása nagyon ritka és általában már intrauterin vagy perinatalisan halálos.

\section{Terápiás alkalmazás}

Hiány esetén pótlás szükséges. Célszerű a napi mennyiség kétharmad részét reggel és egyharmad részét este bevenni, és olyan szert adni, ami GC- és MC-hatással is bír (kortizon, hidrokortizon vagy prednizon). Stressz esetén kiegészítő adagokra is szükség lehet. Akut mellék- vese-elégtelenség esetén elsődleges a só- és vízháztartás rendezése, míg CAH-ban a hiány jellegének és mértékének megfelelő pótlásra lehet szükség, ami az ACTHszekréciót normalizálja.

Legelterjedtebb a GC-k gyulladásgátló, immunszuppresszív, allergiaellenes hatásainak kihasználása. Ezen hatások ugyanakkor csak palliatívak, az alapbetegséget nem szüntetik meg. Ízületi gyulladás kezelésére már a 40-es évek óta alkalmazzák (kezdetben csodaszerként tekintettek rá, bár hamar kiderültek súlyos mellékhatásai). Asztmában, autoimmun megbetegedésekben, sokkban, kollagénbetegségekben, például szisztémás lupus erythematosusban, nefrózisszindrómában, a csecsemők légzési elégtelensége esetén, agysérülésnél, transzplantátum kilökődésének megelőzésére, rákos betegségek adjuváns terápiájában és számos bőrbetegségben ma is elsőként választandó szer.

Bár a hagyományos szemlélet szerint a gyomorfekély egyik fajtája az úgynevezett stresszulcus, azaz a GC-k kifejezetten károsító szerepét lehet feltételezni, de mégis a GC-k kiterjedten és jó hatásfokkal alkalmazhatók számos gastrointestinalis megbetegedésben is [42]. A jelenség elméleti hátterét adhatja az a felfedezés, miszerint a gyomorfekély képződése során a GC-k alapvetően védőszereppel bírnak [43].

A kezelés elsődleges szempontja, hogy az erős GChatás mellett minél kisebb legyen a szer MC-aktivitása, és a mellékhatások elkerülése érdekében minél lokálisabban, kisebb dózisban és rövidebb ideig alkalmazzuk, továbbá kellően megalapozott indokkal.

\section{Mellékhatások}

A 60 napnál tovább orális GC-kezelésben részesülő betegek $90 \%$-ánál is jelentkezhetnek, még akkor is, ha elég alacsony dózist $(\leq 7,5 \mathrm{mg} /$ nap) szednek [1].

Véraláfutások, izomgyengeség, hízás, bőrelváltozások (striák, lokálisan alkalmazva atrophia), alvászavarok, szürke hályog és patológiás törések is előfordulhatnak. Nem szteroid gyulladásgátlókkal kombinálva a gyomornyálkahártya-károsodás, gyomorvérzés kockázata is nő. Pszichiátriai mellékhatásokként jelentkezhetnek érzelmi zavarok (szorongás, depresszió), delírium vagy pánikbetegség. A GC-k a iatrogén 2-es típusú cukorbetegség leggyakoribb előidézői.

Tartós kezelés az endogén endokrin rendszer múködését is erôteljesen befolyásolja, Cushing-szindróma vagy mellékvese-elégtelenség is kialakulhat. Elhagyása ezért a dózis fokozatos csökkentésével ajánlott. Egy hétnél rövidebb kezelés esetén ez a probléma nem valószínü. A szerek nagy részének van MC-aktivitása is, ami só- és vízretencióhoz, magas vérnyomáshoz vezet hypokalaemiával és alkalosissal.

A mellékhatások kivédéséhez ajánlott kalcium- és Dvitamin-kiegészítés $5 \mathrm{mg} / \mathrm{kg}$ dózis felett. Szükség lehet még biszfoszfonátokra, pszichotrop szerekre, a cukorbetegség kezelésére is. 
Megoldás lehet egy eddiginél is célzottabb terápiás alkalmazás (például nanopartikulumok [44]), vagy kombinált szerek használata (például a GC-agonista mellé adott MR-antagonista kivédi a felületi kezelés bőrkárosító hatását [45]). Mivel a krónikus GC-kezelés az endogén anabolikus DHEA-termelést is gátolja, felmerült az is, hogy krónikus GC-kezelés kiegészítéseként DHEA-t kellene adni [46].

Anyagi támogatás: A közlemény megírása anyagi támogatásban nem részesült.

Szerzôi munkamegosztás: Z. D. és M. B. G. egyenlő arányban vett részt a dolgozat koncepciójának kialakításában és a megszövegezésében. A kézirat végleges változatát mindkét szerző elolvasta és jóváhagyta.

Érdekeltségek: A szerzőknek nincsenek érdekeltségeik.

\section{Irodalom}

[1] Ericson-Neilsen, W., Kaye, A. D.: Steroids: pharmacology, complications, and practice delivery issues. Ochsner J., 2014, 14(2), 203-207.

[2] Selye, H.: A syndrome produced by diverse nocuous agents. 1936. J. Neuropsychiatry Clin. Neurosci., 1998, 10(2), 230a231

[3] Szabo, S., Tache, Y., Somogyi, A.: The legacy of Hans Selye and the origins of stress research: A retrospective 75 years after his landmark brief "Letter" to the Editor of Nature. Stress, 2012, 15(5), $472-478$.

[4] http://rheumatology.oxfordjournals.org/cgi/content/ full $/ 41 / 5 / 582$

[5] Fonyó, A., Ligeti, E.: Textbook of medicinal physiology. [Az orvosi élettan tankönyve.] Medicina Könyvkiadó, Budapest, 2008. [Hungarian]

[6] Ota, A., Mase, J., Howteerakul, N., et al.: The effort-reward imbalance work-stress model and daytime salivary cortisol and dehydroepiandrosterone (DHEA) among Japanese women. Sci. Rep., 2014, 4, 6402.

[7] Taves, M. D., Gomez-Sanchez, C. E., Soma, K. K.: Extra-adrenal glucocorticoids and mineralocorticoids: evidence for local synthesis, regulation, and function. Am. J. Physiol. Endocrinol. Metab., 2011, 301(1), E11-E24.

[8] Wosu, A. C., Valdimarsdóttir, U., Shields, A. E., et al.: Correlates of cortisol in human hair: implications for epidemiologic studies on health effects of chronic stress. Ann. Epidemiol., 2013, 23(12), 797-811.e2.

[9] Spiga, F., Waite, E. J., Liu, Y., et al.: ACTH-dependent ultradian rhythm of corticosterone secretion. Endocrinology, 2011, $152(4), 1448-1457$.

[10] Walker, J. J., Spiga, F., Waite, E., et al.: The origin of glucocorticoid hormone oscillations. PLoS Biol., 2012, 10(6), el001341.

[11] Schülke, B., Tegeler, G.: Relationship between the quality of dietary proteins and the functional status of the adrenal cortex. Variations in the content of transcortion, free corticosterone and total corticosterone in the blood plasma of rats fed with proteins of various quality. Arch. Tierernahr., 1975, 25(6), 453-462.

[12] Moisan, M. P., Minni, A. M., Dominguez, G., et al.: Role of corticosteroid binding globulin in the fast actions of glucocorticoids on the brain. Steroids, 2014, 81, 109-115.

[13] Katayama, S., Yamaji, T.: A binding-protein for aldosterone in human plasma. J. Steroid Biochem., 1982, 16(2), 185-192.
[14] Nicolaides, N. C., Galata, Z., Kino, T., et al.: The human glucocorticoid receptor: molecular basis of biologic function. Steroids, 2010, 75(1), 1-12.

[15] De Kloet, E. R.: From receptor balance to rational glucocorticoid therapy. Endocrinology, 2014, 155(8), 2754-2769.

[16] Haller, J., Mikics, E., Makara, G. B.: The effects of non-genomic glucocorticoid mechanisms on bodily functions and the central neural system. A critical evaluation of findings. Front. Neuroendocrinol., 2008, 29(2), 273-291.

[17] Liu, X., Wang, C. A., Chen, Y. Z.: Nongenomic effect of glucocorticoid on the release of arginine vasopressin from hypothalamic slices in rats. Neuroendocrinology, 1995, 62(6), 628-633.

[18] Dooley, R., Harvey, B. J., Thomas, W.: Non-genomic actions of aldosterone: from receptors and signals to membrane targets. Mol. Cell. Endocrinol., 2012, 350(2), 223-234.

[19] Gauer, S., Segitz, V., Goppelt-Struebe, M.: Aldosterone induces CTGF in mesangial cells by activation of the glucocorticoid receptor. Nephrol. Dial. Transplant., 2007, 22(11), 3154-3159.

[20] Makara, G. B., Harbuz, M. S., Coventry, T. L., et al.: The effect of hypothalamic lesions on hypothalamo-pituitary-adrenal axis activity and inflammation in adjuvant-induced arthritis. Stress, 2001, 4(1), 25-37.

[21] Zelena, D., Filaretova, L., Mergl, Z., et al.: Hypothalamic paraventricular nucleus, but not vasopressin, participates in chronic hyperactivity of the HPA axis in diabetic rats. Am. J. Physiol. Endocrinol. Metab., 2006, 290(2), E243-E250.

[22] Makara, G. B., Varga, J., Barna, I., et al.: The vasopressin-deficient Brattleboro rat: lessons for the hypothalamo-pituitary-adrenal axis regulation. Cell. Mol. Neurobiol., 2012, 32(5), 759766.

[23] Bornstein, S. R., Engeland, W. C., Ehrhart-Bornstein, M., et al.: Dissociation of ACTH and glucocorticoids. Trends Endocrinol. Metab., 2008, 19(5), 175-180.

[24] Varga, J., Ferenczi, S., Kovács, K. J., et al.: Comparison of stressinduced changes in adults and pups: is aldosterone the main adrenocortical stress hormone during the perinatal period in rats? PLoS ONE, 2013, $8(9)$, e72313.

[25] Elifanov, A. V., Polenov, A. L., Belen'kiu, M. A., et al.: Morphofunctional research on the interrenal gland of the frog Rana temporaria following arginine vasotocin administration. Zh. Evol. Biokhim. Fiziol., 1988, 24(5), 740-744.

[26] Sapolsky, R. M., Romero, L. M., Munck, A. U.: How do glucocorticoids influence stress responses? Integrating permissive, suppressive, stimulatory, and preparative actions. Endocr. Rev., 2000, 21(1), 55-89.

[27] Sapolsky, R. M.: McEwen-induced modulation of endocrine history: a partial review. Stress, 1997, 2(1), 1-12.

[28] Rose, A. J., Herzig, S.: Metabolic control through glucocorticoid hormones: an update. Mol. Cell. Endocrinol., 2013, 380(1-2), 65-78.

[29] Uchoa, E. T., Aguilera, G., Herman, J. P., et al.: Novel aspects of glucocorticoid actions. J. Neuroendocrinol., 2014, 26(9), 557572.

[30] Sorrells, S. F., Caso, J. R., Munhoz, C. D., et al.: The stressed CNS: when glucocorticoids aggravate inflammation. Neuron, 2009, 64(1), 33-39.

[31] Johnson, J. D., O'Connor, K. A., Deak, T., et al.: Prior stressor exposure sensitizes LPS-induced cytokine production. Brain Behav. Immun., 2002, 16(4), 461-476.

[32] Li, X. Q., Zhu, P., Myatt, L., et al.: Roles of glucocorticoids in human parturition: a controversial fact? Placenta, 2014, 35(5), 291-296.

[33] Gobinath, A. R., Mahmoud, R., Galea, L. A.: Influence of sex and stress exposure across the lifespan on endophenotypes of depression: focus on behavior, glucocorticoids, and hippocampus. Front. Neurosci., 2014, 8, 420.

[34] Engel, G. L.: The biopsychosocial model and the education of health professionals. Ann. N. Y. Acad. Sci., 1978, 310, 169-181. 
[35] Daskalakis, N. P., Bagot, R. C., Parker, K. J., et al.: The three-hit concept of vulnerability and resilience: toward understanding adaptation to early-life adversity outcome. Psychoneuroendocrinology, 2013, 38(9), 1858-1873.

[36] Wingenfeld, K., Wolf, O. T.: Stress, memory, and the hippocampus. Front. Neurol. Neurosci., 2014, 34, 109-120.

[37] Haller, J.: The glucocorticoid/aggression relationship in animals and humans: an analysis sensitive to behavioral characteristics, glucocorticoid secretion patterns, and neural mechanisms. Curr. Top. Behav. Neurosci., 2014, 17, 73-109.

[38] Delahanty, D. L., Raimonde, A. J., Spoonster, E.: Initial posttraumatic urinary cortisol levels predict subsequent PTSD symptoms in motor vehicle accident victims. Biol. Psychiatry, 2000, 48(9), 940-947.

[39] Vinson, G. P.: The adrenal cortex and life. Mol. Cell. Endocrinol., 2009, 300(1-2), 2-6.

[40] Zelena, D., Makara, G. B.: The role of adrenocorticotropin beyond the glucocorticoid horizon. In: Berhardt, L. V. (ed.): Advances in medicine and biology. Vol. 43. Nova Science Publisher, 2012.

[41] Tierney, L. M., McPhee, S. J., Papadakis, M. A.: Current medical diagnosis and treatment 2007. [Korszerú orvosi diagnosztika és terápia 2007.] Melania Kiadó, Budapest, 2008. 1996. [Hungarian]
[42] Triadafilopoulos, G.: Glucocorticoid therapy for gastrointestinal diseases. Expert Opin. Drug Saf., 2014, 13(5), 563-572.

[43] Filaretova, L. P.: Activation of the hypothalamo-hypophysealadrenocortical system as an important gastroprotective component of the stress reaction. Neurosci. Behav. Physiol., 2007, $37(4), 355-362$.

[44] Fredman, G., Kamaly, N., Spolitu, S., et al.: Targeted nanoparticles containing the proresolving peptide Ac2-26 protect against advanced atherosclerosis in hypercholesterolemic mice. Sci. Transl. Med., 2015, 7(275), 275ra20.

[45] Maubec, E., Laouénan, C., Deschamps, L., et al.: Topical mineralocorticoid receptor blockade limits glucocorticoid-induced epidermal atrophy in human skin. J. Invest. Dermatol., 2015, 135(7), 1781-1789

[46] Robinzon, B., Cutolo, M.: Should dehydroepiandrosterone replacement therapy be provided with glucocorticoids? Rheumatology (Oxford), 1999, 38(6), 488-495.

(Zelena Dóra dr., Budapest, Szigony u. 43., 1083 e-mail: zelena.dora@koki.mta.hu)

\section{A rendezvények és kongresszusok híranyagának leadása}

a lap megjelenése előtt legalább 40 nappal lehetséges, a 6 hetes nyomdai átfutás miatt. Kérjük megrendelőink szíves megértését.

A híranyagokat a következő címre kérjük:

Orvosi Hetilap titkársága: Budai.Edit@akkrt.hu

Akadémiai Kiadó Zrt. 